\title{
Effects of herd management practices on somatic cell counts in an arid climate
}

\author{
Ali Sadeghi-Sefidmazgi ${ }^{1}$, Farahnaz Rayatdoost-Baghal ${ }^{2}$
}

\author{
${ }^{1}$ Department of Animal Science, College of Agriculture, Isfahan University of Technology, Isfahan, Iran \\ ${ }^{2}$ Vahdat Cooperative Ltd., Isfahan, Iran.
}

\begin{abstract}
The objective of this study was to evaluate associations between average lactation somatic cell counts (SCC) and herd management practices in an arid climate. A total of 38,530 average lactation SCC records for 10,216 Holstein cows gathered on 25 dairy farms from January 2009 to October 2012 in Isfahan (Iran) were analyzed. Average lactation SCC (cells $\times 1,000$ ) was 250.79 ranging from 90.31 to 483.23 cells $/ \mathrm{mL}$ across investigated farms. Herd-level management factors associated with average lactation SCC were determined separately using mixed linear models in the MIXED procedure with average lactation somatic cell score (SCS) included as the dependent variable. Some of the management practices associated with low average lactation SCS included sawdust combined with sand bedding, using automatic cup removers, disinfection of the teats by dipping into disinfectant, using washable towels for teat cleaning, free-stall barns, wet disposable tissue for udder washing, wearing gloves during milking and the use of humidifiers and shade. Lower-production herds and larger-size herds had lower average lactation somatic cell counts. Most herd management practices associated with average lactation SCC in dairy herds in the arid region of Isfahan are in agreement with most previous studies. However, different results are found for use of humidifier, bedding materials and herd size.
\end{abstract}

Key Words: dairy cattle, mastitis control program, somatic cell score

\section{Introduction}

Mastitis is an udder health disorder that causes substantial economic losses including discarded milk, veterinary treatments, decrease in milk yield and quality, reduced lactation persistency, early culling, and increased labor and replacement costs. Furthermore, mastitis considerably reduces animal welfare and milk processing ability (Seegers et al., 2003; Sadeghi-Sefidmazgi et al., 2011). This inflammation of the mammary gland, usually in response to invasive agents, can be characterized by an increase in the somatic cell count (SCC) in milk (Mehrzad et al., 2010). This trait or its logarithmic transform, called somatic cell score (SCS), are widely used as an indicator of udder health of both the entire herd and the individual cow for management and selection purposes (Rodriguez-Zas et al., 2000).

It is important to know which hygiene and management practices to adopt to decrease SCC and therefore the prevalence of intramammary infection. There are numerous studies from developed countries (e.g., Barkema et al., 1998; Barnouin et al., 2004; Wenz et al., 2007) where associations

Received May 13, 2014 and accepted July 20, 2014

Corresponding author: sadeghism@cc.iut.ac.ir

http://dx.doi.org/10.1590/S1516-35982014000900007

Copyright (@) 2014 Sociedade Brasileira de Zootecnia. This is an Open Access article distributed under the terms of the Creative Commons Attribution Non-Commercial License, which permits unrestricted non-commercial use, distribution, and reproduction in any medium, provided the original work is properly cited. between management practices and SCC in bulk tank or herd mean levels were determined. However, there is no report of associations between herd management practices and average lactation SCC in developing countries with arid climates, and the importance of management factors could vary from country to country. This can partially be due to different production systems as well as climate conditions.

The objective of this study was to evaluate associations between average lactation SCC and herd management practices in an arid climate using mixed linear models. Results of this research can be used to identify the most important variables to study in order to promote best management practices to lower SCC.

\section{Material and Methods}

Farms were selected from the 60 dairy herds in Isfahan (Iran) participating in the Dairy Herd Improvement (DHI) program in 2006. From these herds, only 25 that had available and reliable information for all investigated variables were selected. Farms were of different sizes (Table 1), animals were housed differently across the farms and each had their own specific feeding and management policies. In all farms, cows were fed a balanced total mixed ration. For all farms, somatic cell counts were measured on the basis of individual cow milk samples by means of Fossomatic ${ }^{\mathrm{TM}}$ FC (Foss Electric, Hillerød, Denmark). 
Table 1 - Descriptive statistics for somatic cell count, herd size and milk yield on 25 Isfahan dairy farms

\begin{tabular}{lcccccc}
\hline Variable & $\mathrm{N}$ & Mean & Median & Standard deviation & Minimum & Maximum \\
\hline ALSCC & 38530 & 210.45 & 72.54 & 458.42 & 2.00 & 17242.00 \\
ALSCS & 38530 & 2.78 & 2.54 & 1.79 & -2.64 & 10.43 \\
Herd ALSCC & 25 & 250.79 & 251.09 & 117.27 & 90.31 \\
Herd size (milking cows) & 25 & 767.36 & 446.00 & 839.77 & 72.00 \\
Herd 305-d MY & 25 & 10912.91 & 10877.24 & 822.34 & 8963.11 & 12172.73 \\
\hline
\end{tabular}

$\mathrm{N}$ - number of observations; ALSCC - average lactation somatic cell count (cells $10^{3} / \mathrm{mL}$ ); ALSCS - average lactation somatic cell score; Herd 305 -d MY - Herd average 305 -day milk yield per cow $(\mathrm{kg})$.

Samples were transported at $4{ }^{\circ} \mathrm{C}$ to the laboratory and analyzed within 2 and $12 \mathrm{~h}$ after collection, respectively.

The dataset used for the calculations included a total of 249,029 test-day SCC records across the 25 farms for 10,216 Holstein cows gathered from January 2009 to October 2012. Somatic cell counts have a lognormal distribution and were $\log$-transformed to somatic cells score $\left(\mathrm{SCS}=\log _{2}(\mathrm{SCC} /\right.$ $100,000$ cells $)+3)$ ) to achieve an approximate normal distribution of test-day records for the statistical analysis (Ali and Shook, 1980). Finally, average lactation SCS was calculated as the arithmetic mean of all observations per cow through lactation. All investigated farms had at least 170 average lactation SCS records calculated from at least three test-day SCC. A total of 38,530 ALSCS were used for analyses.

Statistical procedures were conducted using SAS/STAT 9.1 (SAS Institute Inc., Cary, NC). The distribution of management practices across herds was determined using the frequency procedure (PROC FREQ). Data for average lactation somatic cell score were analyzed using a mixed linear model (PROC MIXED) with class statements for management factor, herd, and parity. The statistical model used for analyses was:

$y_{i j k l}=\mu+\psi_{i}+\pi_{j}+\theta_{k}+\beta_{l l} \times\left(\alpha_{i j l}-\bar{\alpha}\right)+\lambda_{i j k}+u_{n}+e_{i j k l}$

in which $y_{i j k l}=$ observation, i.e., average lactation somatic cell score $i j k l ; \mu=$ the overall mean; $\psi_{i}=$ the fixed effect of herd $i ; \pi_{j}=$ the fixed effect of parity $j ; \theta_{k}=$ the fixed effect of management factor $k$ (e.g., bedding materials); $\beta_{l l}=$ regression coefficient of observations on $305-\mathrm{d}$ milk yield $\left(\alpha_{i j l}\right)$ as a covariate; $\lambda_{i j k}=$ the fixed effect of the 3-way interactions among herd $i$, parity $j$ and management factor $k$; $u_{n}=$ the random effect of cow $n ; e_{i j k l}=$ random residual effect with mean 0 and homogenous variance $\sigma^{2}$. All herd management factors were analyzed individually in separate mixed models. For all statistical analyses, significance was declared at $\mathrm{P}<0.05$ and trends at $\mathrm{P} \leq 0.10$. The ANOVA method and therefore mean comparisons may be biased because of a lack of normality in our data set. Although the Shapiro-Wilk test detected a departure from normal distribution for average lactation SCS $(\mathrm{P}<0.05)$, the plot of average lactation SCS residuals for all management factors was reasonably close to normal. For example, residuals of the model for teat disinfection type had a low value for skewness (0.18) and kurtosis (-0.09) (Figure 1).

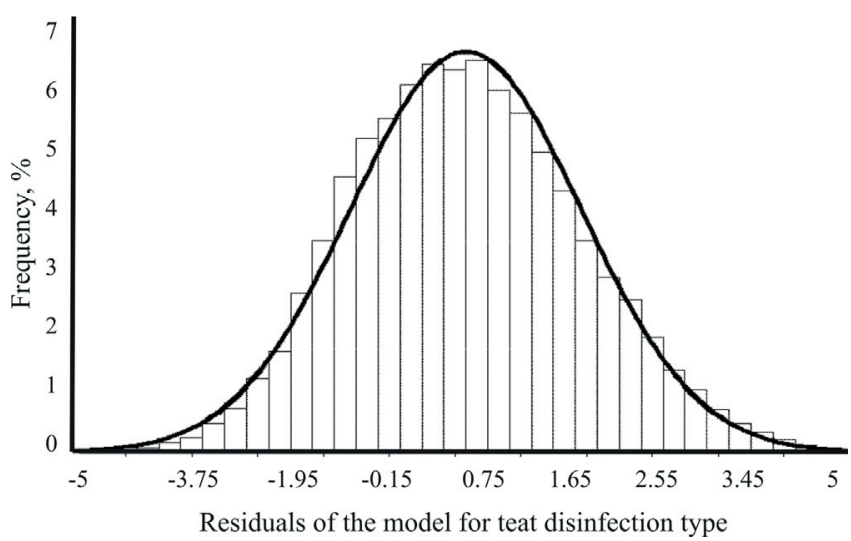

Figure 1 - Histogram plot for residuals of average lactation somatic cell score (SCS) relative to normal distribution (solid line) for teat disinfection type.

\section{Results}

Average lactation SCC (cells $\times 1,000)$ was 250.79 ranging from 90.31 to 483.23 cells $/ \mathrm{mL}$ across investigated farms; the median average lactation SCC $($ cells $\times 1,000)$ was 251.09 cells $/ \mathrm{mL}$ for the farms. The average number of milking cows per herd was 767.36, ranging from 72 to 3,110 cows. The herd average $305-\mathrm{d}$ milk yield was $10,913 \mathrm{~kg}$ per cow and ranged from 8,963 to $12,173 \mathrm{~kg}$ (Table 1 ).

In this study, a total of 13 herd management practices including health, milking and housing conditions were examined for significant relationships with average lactation SCC.

For all investigated management practices, 3-way interactions among herd, parity and management factor and 305-d milk yield as a covariate were highly significant $(\mathrm{P}<0.001)$. But the least square means for class and the regression coefficients for covariate variables were not shown.

There was considerable variation in the herd management practices conducted and the infrastructure (e.g., housing, hygiene) in investigated dairy farms. In general, all of the investigated management practices were associated with average lactation SCS $(\mathrm{P}<0.0001)$, except 
milking frequency $(\mathrm{P}=0.8439)$, and use of humidifier, which showed a tendency $(\mathrm{P}=0.0817)$ for an association with SCS (Table 2).
Most of study farms (72\%) used sand bedding while only a few of them used straw or sawdust (4\%). Cows bedded on straw had the highest average lactation SCC,

Table 2 - Frequency and least square means of factors associated with average lactation somatic cell score (back transformed average lactation somatic cell count $\times 10^{3} / \mathrm{mL}$ in parentheses) on 25 Isfahan dairy farms by herd level

\begin{tabular}{|c|c|c|c|c|}
\hline Management variables & Herd, $\%$ & ALSCS (ALSCC) & $\mathrm{SE}( \pm \mathrm{ALSCS})$ & P-value ${ }^{1}$ \\
\hline Bedding material & & & & $<0.0001$ \\
\hline Dried manure and sand & 8.00 & $3.66(158) \mathrm{a}$ & 0.316 & \\
\hline Sand & 72.00 & $3.48(136) \mathrm{a}$ & 0.065 & \\
\hline Sand combined with straw or sawdust & 12.00 & $3.27(146) \mathrm{a}$ & 0.076 & \\
\hline Sawdust combined with sand & 4.00 & $2.90(93) b$ & 0.047 & \\
\hline Straw & 4.00 & $4.62(308) c$ & 0.108 & \\
\hline Cluster removal system & & & & $<0.0001$ \\
\hline Automatic & 48.00 & 3.35 (127)a & 0.024 & \\
\hline Manual & 28.00 & $3.96(195) b$ & 0.193 & \\
\hline Semiautomatic $^{2}$ & 24.00 & $3.29(122) \mathrm{a}$ & 0.046 & \\
\hline Herd average 305 -day milk yield, kg & & & & $<0.0001$ \\
\hline$<10,000$ & 16.00 & $2.94(96) \mathrm{a}$ & 0.017 & \\
\hline$>10,000$ & 84.00 & $3.15(111) b$ & 0.059 & \\
\hline Herd size (milking cows) & & & & $<0.0001$ \\
\hline$<100$ & 4.00 & $3.85(181) \mathrm{a}$ & 0.129 & \\
\hline 100 to 200 & 16.00 & $3.35(128) b$ & 0.047 & \\
\hline 200 to 500 & 36.00 & $3.14(110) \mathrm{c}$ & 0.022 & \\
\hline 500 to 1,000 & 20.00 & $3.05(103) \mathrm{d}$ & 0.020 & \\
\hline$>1,000$ & 24.00 & $2.58(74) \mathrm{e}$ & 0.012 & \\
\hline Milking frequency & & & & 0.8439 \\
\hline 3 & 76.00 & $3.86(181) \mathrm{a}$ & 0.058 & \\
\hline 4 & 24.00 & $3.88(184) \mathrm{a}$ & 0.109 & \\
\hline Milking machine brand & & & & $<0.0001$ \\
\hline A & 12.00 & $3.81(175) \mathrm{a}$ & 0.576 & \\
\hline $\mathrm{B}$ & 4.00 & $3.11(108) b$ & 0.140 & \\
\hline $\mathrm{C}$ & 84.00 & 3.94 (191)a & 0.053 & \\
\hline Teat cleaning material ${ }^{3,4}$ & & & & $<0.0001$ \\
\hline No cleaning & 36.00 & $3.51(143) \mathrm{a}$ & 0.162 & \\
\hline Straw paper & 16.00 & $2.95(96) \mathrm{b}$ & 0.026 & \\
\hline Tissue paper & 12.00 & $3.39(131) \mathrm{a}$ & 0.032 & \\
\hline Washable towel & 4.00 & $2.55(73) \mathrm{c}$ & 0.044 & \\
\hline Paper towel & 32.00 & $4.06(208) d$ & 0.137 & \\
\hline Teat disinfection type & & & & $<0.0001$ \\
\hline Dipping & 84.00 & $3.41(132) \mathrm{a}$ & 0.067 & \\
\hline Spraying & 8.00 & $3.61(152) b$ & 0.042 & \\
\hline Spraying or dipping & 4.00 & $4.62(307) \mathrm{c}$ & 0.108 & \\
\hline No disinfection & 4.00 & $4.81(352) \mathrm{d}$ & 0.097 & \\
\hline Type of barn & & & & $<0.0001$ \\
\hline Free stall & 60.00 & $3.31(124) \mathrm{a}$ & 0.080 & \\
\hline Open-shed & 28.00 & $3.89(185) b$ & 0.096 & \\
\hline Free stall and open-shed & 12.00 & $3.56(147) \mathrm{c}$ & 0.060 & \\
\hline Udder washing material $^{4}$ & & & & $<0.0001$ \\
\hline Wet tissue & 52.00 & $3.11(108) \mathrm{a}$ & 0.020 & \\
\hline Warm water & 48.00 & $3.90(187) b$ & 0.115 & \\
\hline Use of humidifier ${ }^{5}$ & & & & 0.0817 \\
\hline Yes & 80.00 & 3.37 (129)a & 0.051 & \\
\hline No & 20.00 & $3.58(150) \mathrm{a}$ & 0.113 & \\
\hline Use of gloves & & & & $<0.0001$ \\
\hline No & 52.00 & 3.95 (194)a & 0.127 & \\
\hline Yes & 48.00 & $3.13(110) b$ & 0.017 & \\
\hline Use of shade ${ }^{6}$ & & & & $<0.0001$ \\
\hline No & 96.00 & $3.80(174) \mathrm{a}$ & 0.031 & \\
\hline Yes & 4.00 & $3.44(136) b$ & 0.060 & \\
\hline
\end{tabular}

ALSCS - average lactation somatic cell score (ALSCC - average lactation somatic cell count); SE - standard error.

${ }^{1}$ Type- 3 test for fixed effect of interest in mixed model.

${ }^{2}$ Automatic vacuum reduction or removal but manual cluster removal.

${ }^{3}$ All materials were disposable (except washable towel), single use and dry prior to use.

${ }^{4}$ Conducted before cluster attachment.

${ }^{5}$ Used only during heat stress depending on management decision at least for 2-3 months.

${ }^{6}$ Provided at free-stall as well as loafing area.

a,b,c,d,e - means in a column (within management variable) with the same letter are not significantly different $(\mathrm{P}<0.05)$. 
while the sawdust-with-sand-bedded cows showed the lowest average lactation SCC. Cows bedded on sawdust combined with sand had 32-70\% lower average lactation SCC compared with cows bedded on other materials.

Forty-eight, 28 and 24\% of farms applied an automatic, manual and semiautomatic cluster removal system, respectively; the manual system was associated with the highest average lactation SCC. Least square means results showed that average lactation SCC in the manual system was roughly 1.5 times higher than automatic or semiautomatic cluster removal system.

Sixteen percent of study farms had an average 305-day milk yield $<10,000 \mathrm{~kg}$, which was associated with a lower average lactation SCC compared with herds producing $>10,000 \mathrm{~kg}$ milk $\left(\mathrm{P}<0.001 ; 111\right.$ vs. $96 \times 10^{3}$ cells $/ \mathrm{mL}$ for herds producing $>10,000 \mathrm{~kg}$ vs. $<10,000 \mathrm{~kg}$ milk).

Eighty percent of herds had $>200$ cows. As herd size increased, average lactation SCC decreased such that farms with $<100$ and $>1,000$ milking cows had the highest and lowest average lactation SCC, respectively. The least square means results showed that herd size $>1,000$ milking cows had 28-59\% lower average lactation SCC compared with other herd size group $(\mathrm{P}<0.05)$.

Seventy-six percent of farms practiced milking three times a day, whilst the remainder milked four times per day, but there was no association between the number of milkings per day and average lactation SCC $(\mathrm{P}=0.8439)$.

The majority of farms (84\%) used a milking machine brand $(\mathrm{C})$ which was not the brand with lowest average lactation SCC (B). Average lactation SCC in the most common brand (C) was 1.8 higher than the best brand (B).

The majority of farms $(64 \%)$ conducted regular teatcleaning practices. The use of dry washable towels was associated with the lowest average lactation SCC, whereas teat cleaning with dry paper towels was associated with an average lactation SCC, which was significantly higher than the $36 \%$ of farms with no teat cleaning. The least square means results showed that use of dry washable towels for teat cleaning would result in approximately 24-65\% lower average lactation SCC compared with other cleaning materials $(\mathrm{P}<0.05)$.

The most common type of barns was free-stall (60\%) followed by open shed $(12 \%)$. Herds that housed cows in a combination of free-stall and open-shed barns had the lowest and highest average lactation SCC, respectively. The least square means results showed that open-shed barns had 26-49\% higher average lactation SCC compared with other barn types $(\mathrm{P}<0.05)$.

The majority of farms (84\%) used post-milking dipping for teat disinfection and had the lowest average lactation
SCC, while the small proportion of farms which applied no disinfection (4\%) had the highest average lactation SCC. Farms without any teat disinfection had 1.1-2.7 higher average lactation SCC compared with those using teat disinfection.

Fifty-two percent of farms used warm water for premilking udder/teat washing and had a higher average lactation SCC compared with herds that used wet tissue $(\mathrm{P}<0.001$; 187 vs. $108 \times 10^{3}$ cells $/ \mathrm{mL}$ for wet tissue vs. warm water).

Wearing gloves during milking (52\%) was strongly associated with lower herd SCC. The least square means results showed that farms using gloves during milking had $43 \%$ lower average lactation SCC compared with other farms $(\mathrm{P}<0.05)$.

Most (96\%) study farms provided shade for cows and had a lower average lactation SCC. Herds provided with shade had 22\% lower average lactation SCC compared with other farms $(\mathrm{P}<0.05)$.

The majority of farms $(80 \%)$ used a humidifier (at the managers discretion) in the free-stall and loafing areas for cows, which showed a tendency to be associated with lower herd SCC $\left(\mathrm{P}=0.08 ; 129\right.$ vs. $150 \times 10^{3}$ cells $/ \mathrm{mL}$ for farms with humidifier vs. no humidifier).

\section{Discussion}

In the dairy industry, not only milk production but also milk quality is of importance. Therefore, it is essential that herd management factors associated with milk quality be quantified. This research investigated associations between management practices, system design and performance and average lactation SCC in the herd in an arid climate.

In contrast to other studies summarized by Dufour et al. (2011) in a systematic literature review, our results show that herds that bedded cows on sawdust combined with sand had the lowest average lactation SCC. Generally, sand or sand combined with sawdust or straw bedding was strongly associated with lower herd SCC.

The results on cluster removal system were in agreement with the findings of other studies: based on obtained results in the study and most of literature as reviewed by Dufour et al. (2011). Therefore, it can be concluded that automatic cluster removal system is associated with lower SCC given that being well-adjusted also in our production systems.

By increasing 305-day milk yield, average lactation SCC was increased. This was not surprising due to positive association between milk yield and SCC (Batavani et al., 2007).

There was a negative association between herd size and SCC, which was also observed by Allore et al. (1997) and 
Oleggini et al. (2001). The lower average lactation SCC observed in lager herds were likely to be associated with increased farmer knowledge of individual cows SCC and mastitis. In large farms, consultants and veterinarians are commonly employed to provide advice on management and system design. Therefore, farmers were more aware of the mastitis status of the herd and had lower SCC (Kelly et al., 2009). Importantly, these results suggest expansion may be associated with decreased cow SCC assuming that with expansion comes an increased level of knowledge and focus on factors impacting on udder health.

It is generally expected that a higher milking frequency impairs teat condition and increases somatic cell counts through an increased cups-on time rather than as a direct effect of the frequency of milk removal from the gland (Ouweltjes et al., 2007). This general conclusion was not supported by our results suggesting no significant benefits for 3 versus 4 times milking a day $(P=0.84)$. This result also was in disagreement with the findings of other studies indicating that an increased milking frequency can be associated with a lower SCC, particularly at lower frequencies; 3-time daily milking compared with twicedaily milking lowered SCC (Smith et al., 2002). Dahl et al. (2004) reported the same trend for milking six times compared with three times daily. This controversy was partially described by Waterman et al. (1983), who concluded that milking frequency itself did not affect overall udder health, whereby a decrease in SCC is generally regarded as an indication of improved udder health management and protocols. In practice, practical decisions on milking frequency on the base of cost-benefit analysis at specific stages of lactation and individual cow production has been recommended (Jacobs and Siegford, 2012).

Use of various milking machine brands resulted in statistically different average lactation SCC. Effects of automatic milking on udder health of dairy cows were discussed in detail by Hovinen and Pyörälä (2011).

Use of a washable towel for teat cleaning had the lowest average lactation SCC among different materials used, in agreement with Barkema et al. (1998) and Kelly et al. (2009), who reported that teat cleaning is one of the most important factors associated with lower SCC. However, based on our results, use of a dry paper towel for teat cleaning is not recommendable. It was also apparent that straw paper was preferable over tissue paper.

Teat disinfection after milking reduced average lactation SCC, with dipping being the best type of teat disinfection. This is in agreement with Barkema et al. (1998), who reported that the most important factors associated with bulk tank SCC was teat disinfection after milking. Lower
SCS was observed on farms that disinfected teats after every milking, as reported by Kelly et al. (2009).

Herds that housed cows on free-stall barns had the lowest average lactation SCC. Free-stall housing provided a more desirable environment for the herds than other barns. Udder health (as evaluated through the SCC) is expected to be improved in free-stall barns, as reported in previous studies (e.g. Smith et al., 1997).

Average lactation SCC was significantly impacted by pre-milking udder washing procedure. Use of wet tissue was strongly associated with lower herd SCC in comparison with warm water. According to Koster et al. (2006), use of water to clean the udders before milking has been associated with high SCC because water fluxing along the udder can carry bacteria to the tip of the teat thereby increasing the risk of mastitis.

Results showed that wearing gloves during milking was strongly associated with lower herd SCC. Kelly et al. (2009) reported no significant decrease in herd SCC for glove-wearing farmers. However, based on a systematic literature review, Dufour et al. (2011) recommended the use of gloves during milking to have a lower SCC.

Average lactation SCC was lower in herds with shade facilities. Farmers that used a humidifier in the barn for cows showed a tendency to have a lower average lactation SCC. Therefore, it can be concluded that farms that provided a more comfortable climatic environment such as shade or humidifier can expect to have a lower risk of mastitis incidence as measured by average lactation SCC. Kadzere et al. (2002) proposed that the influence of heat stress on the physiological functions of the high-producing dairy cow may initiate clinical or subclinical diseases, especially because disease-causing agents are better able to thrive in hot and humid environments. However, our results showed that providing humid environments in an arid climate can potentially reduce herd SCC level.

Including a three-way interaction among herd, parity and management factor improved the goodness of fit level of the model as measured by Akaike's and Bayesian information criteria, AIC and BIC. The interaction was highly significant $(\mathrm{P}<0.001)$, indicating that management practices applied to control SCC and mastitis depending on farm and cow parity might lead to different results. Therefore, each manger needs to apply a specific management to control mastitis based on their farm conditions.

\section{Conclusions}

Most herd management practices associated with average lactation somatic cell count in dairy herds in the 
arid region of Isfahan are in agreement with most previous studies. However, different results are found for use of humidifier, bedding materials and herd size.

\section{Acknowledgments}

The first author (A. Sadeghi-Sefidmazgi) is grateful to the farmers for participating in the study and thanks Simon Dufour (University of Montreal, Canada) and Emilio Ungerfeld (Cien Austral, Universidad Austral de Chile) for statistical advice and reviewing the manuscript.

\section{References}

Ali, A. K. A. and Shook, G. E. 1980. An optimum transformation for somatic cell concentration in milk. Journal of Dairy Science 63:487-490.

Allore, H. G.; Oltenacu, P. A. and Erb, H. N. 1997. Effects of season, herd size, and geographic region on the composition and quality of milk in the Northeast. Journal of Dairy Science 80:3040-3049.

Barkema, H. W.; Schukken, Y. H.; Lam, T. J. G. M.; Beiboer, M. J.; Benedictus, G. and Brand, A. 1998. Management practices associated with low, medium, and high somatic cell counts in bulk milk. Journal of Dairy Science 81:1917-1927.

Barnouin, J.; Chassagne, M.; Bazin, S. and Boichard, D. 2004. Management practices from questionnaire surveys in herds with very low somatic cell score through a national mastitis program in France. Journal of Dairy Science 87:3989-3999.

Batavani, R. A.; Asri, S. and Naebzadeh, H. 2007. The effect of subclinical mastitis on milk composition in dairy cows. I Iranian Journal of Veterinay Research 8:205-211.

Dahl, G. E.; Wallace, R. L.; Shanks, R. D. and Lueking, D. 2004. Hot Topic: Effects of frequent milking in early lactation on milk yield and udder health. Journal of Dairy Science 87:882-885.

Dufour, S.; Fréchette, A.; Barkema, H. W.; Mussell, A. and Scholl, D. T. 2011. Effect of udder health management practices on herd somatic cell count. Journal of Dairy Science 94:563-579.

Hovinen, M. and Pyörälä, S. 2011. Invited review: Udder health of dairy cows in automatic milking. Journal of Dairy Science 94:547-562.

Jacobs, J. A. and Siegford, J. M. 2012. Invited review: The impact of automatic milking systems on dairy cow management, behavior, health, and welfare. Journal of Dairy Science 95:2227-2247.
Kadzere, C. T.; Murphy, M. R.; Silanikove, N. and Maltz, E. 2002. Heat stress in lactating dairy cows: A review. Livestock Production Science 77:59-91.

Kelly, P. T.; O’Sullivan, K.; Berry, D. P.; More, S. J.; Meaney, W. J.; O'Callaghan, E. J. and O'Brien, B. 2009. Farm management factors associated with bulk tank somatic cell count in Irish dairy herds. Irish Veterinary Journal 62:45-52.

Koster, G.; Tenhagen, B. A.; Scheibe, N. and Heuwieser, W. 2006. Factors associated with high milk test day somatic cell counts in large dairy herds in Brandenburg. II. Milking practices. Journal of Veterinary Medicine. A, Physiology, pathology, clinical medicine 53:209-214.

Mehrzad, J.; Paape, M. and Burvenich, C. 2010. Role of neutrophils in protection of udder from infection in high yielding dairy cows. Iranian Journal of Veterinay Research 11:102-118.

Oleggini, G. H.; Ely, L. O. and Smith, J. W. 2001. Effect of region and herd size on dairy herd performance parameters. Journal of Dairy Science 84:1044-1050.

Ouweltjes, W.; Beerda, B.; Windig, J. J.; Calus, M. P. L. and Veerkamp, R. F. 2007. Effects of management and genetics on udder health and milk composition in dairy cows. Journal of Dairy Science 90:229-238.

Rodriguez-Zas, S. L.; Gianola, D. and Shook, G. E. 2000. Evaluation of models for somatic cell score lactation patterns in Holsteins. Livestock Production Science 67:19-30.

Sadeghi-Sefidmazgi, A.; Moradi-Shahrbabak, M.; Nejati-Javaremi, A.; Miraei-Ashtiani, S. R. and Amer, P. R. 2011. Estimation of economic values and financial losses associated with clinical mastitis and somatic cell score in Holstein dairy cattle. Animal 5:33-42.

Seegers, H.; Fourichon, C. and Beaudeau, F. 2003. Production effects related to mastitis and mastitis economics in dairy cattle herds. Veterinary Research 34:475-491.

Smith, J. W. and Ely, L. O. 1997. The influence of feeding and housing systems on production, reproduction, and somatic cell count scores of southern Holstein herds. The Professional Animal Scientist 13:155-161.

Smith, J. W.; Ely, L. O.; Graves, W. M. and Gilson, W. D. 2002. Effect of milking frequency on DHI performance measures. Journal of Dairy Science 85:3526-3533.

Waterman, D. F.; Harmon, R. J.; Hemken, R. W. and Langlois, B. E. 1983. Milking frequency as related to udder health and milk production. Journal of Dairy Science 66:253-258.

Wenz, J. R.; Jensen, S. M.; Lombard, J. E.; Wagner, B. A. and Dinsmore, R. P. 2007. Herd management practices and their association with bulk tank somatic cell count on United States dairy operations. Journal of Dairy Science 90:3652-3659. 